\title{
The University Library and the War
}

Miss Christoffers, reference librarian, University of $W$ ashington, read this paper at the meeting of the University Libraries Section of A.C.R.L., June 24, 1942.

$\mathrm{T}$ HE UNIVERSITY LIBRARY and the war-what part can it play in the rapidly changing scene?-that is a question of deepest concern to us all. We have been swept off our feet by the sudden impact of war. What can we do to contribute? How be a part of the war effort? How justify our existence? We have the urge to accomplish great things, to do more than we have ever done before, something dramatic, unusual, spectacular. We have talked much and written at length on morale, democracy, the library in national defense. Most of us have formed definite opinions as to what our place should be.

It seems to me that our greatest contribution to the war is to continue business as usual. One of the qualities of the British that we have admired most is their ability to go on with their daily tasks maintaining as nearly normal a trend of life as is possible in the face of desperate obstacles. The university is the great educative body. The library is its handmaiden. Without books the educative process is weakened. Books are our weapons as well as our tools. We have certain established routines which enable us to function in war or in peace. Books must be purchased, processed, and circulated. Periodicals must be available for research. Every effort must be made to keep our files intact on all fronts. We must step up our service, step up our production, do away with needless discussion of methods, and strive for more and better business. We must advertise our wares, display our acquisitions, back up our faculty and students by supplying their daily needs.

Reports from many libraries indicate a decrease in circulation since the beginning of the war. This trend was to be expected. Students have been busy adjusting themselves to changes in living, to the idea of participating in active service. Increased opportunities for employment have shortened their leisure hours. Faculty members have left and courses been dropped or changed in emphasis. A public equipping itself for a new task has little time for reading. All this will change. As we settle down to the long pull, as we become more stabilized in our thinking, reading will again return to its place in the school and the home.

To be ready for this change we must keep up our supply of books-books for information, inspiration, recreation. Reading requests must be anticipated. We must know our collections better, be able to substitute books just as good for those we cannot supply. Needs change rapidly-one month we need books on Latin America, the next on Germany, Japan, Australia, China, Russia, or Siberia. The market is flooded with books. We are harried by high pressure adver- 
tising. Some authors have a worthwhile message, others no possible place on our shelves. The utmost care is needed to purchase the best, the most pertinent within the narrow confines of our budget. Book reviews must be read thoughtfully, publishers' advertising campaigns considered, selections made carefully in order that a well-rounded collection adequate for the needs of the institution may be assembled.

\section{Program of Education}

Neither our allies nor our enemies must be neglected. We are preparing for peace as well as war and a peace which we hope will bring well-being to all peoples of the world. We are developing the minds not merely of soldiers but of men and women who will take an active part in building a postwar world. Education is a longrange program. We must prepare for a postwar society-one that will provide a happier, busier, more satisfying life for all. To talk of democracy and the American way of life is of little value without an understanding of what the terms meannot to me alone, but to the "Joads," the Negro, the Nisei. To exercise wisdom in the selection of books which present these problems and to put them into the hands of our students as we discuss with them needs and problems are tasks of the greatest importance. These tasks will not be accomplished unless librarians can maintain an attitude of tolerance. If the war lasts a long time we may have to fight for this right to be tolerant, but it will be worth the fight if we can aid in making a better society.

Decreased enrolments may enable us to do a better job of educating our students than we have done in the past. Perhaps we can learn to know more students as indıviduals, inspire more with a desire for reading, teach more of them how and why to use the library, and help them to form a library habit which will continue throughout their lives. Our failure to do this has been one of our greatest shortcomings.

\section{Needs of Faculty}

In our zeal to find our place in the lives of our students, we must not neglect the needs of our faculty. Many have left to aid the government in important posts, others are engaged in secret research on the home ground. Special needs or special requests for materials needed by these men at home must be met at once. There is no time to waste. Books that cannot be purchased must be borrowed. Each institution must serve every other institution. Cooperation is needed as never before. We of the Pacific Northwest are used to that idea. We have cooperated in many library ventures. We borrow and lend freely among ourselves and from our great southern neighbor, the University of California. We are at present engaged in a survey of our library resources which will make us even more familiar with each other's collections.

Some institutions may hesitate to lend to libraries in war areas. They cannot be condemned for that. They must protect their collections. If such be the case, films and photostats offer a substitute. We may become so used to the idea of films that all our problems of interlibrary loans will be solved.

Our policy of business as usual must not be confined to the boundaries of our campus. We owe a debt to our government, our state, our cities and towns, our Army, our Navy, our civilian population, and the world at large. To stretch our 
facilities over all these areas is a difficult task. Government organizations usually seek us out. Many of their staff members are college men used to library facilities. They may prefer to do their own research or may desire the services of a trained librarian to do research for them. In either case we must be ready to serve, place few restrictions in their way, forget as far as possible strict library rules and regulations which cause useless friction and annoyance, remembering only the need to safeguard materials for future use as well as present.

Library services can be extended to every branch of our Army and Navy by inviting our soldiers and sailors to use our libraries, making them welcome when they visit us, and by lending them books individually or through their service club libraries or chaplains. This can be our contribution to morale-building among our defenders.

The civilian population presents a more difficult problem to the university library except in its own immediate vicinity. In most communities the public library takes care of this problem. However, the faculty can do much to formulate right ideals by arranging and conducting forums and discussion clubs on defense work, postwar planning, and other pertinent subjects. The library will stand by to provide reading lists, books, pamphlets, and bibliographies as a means of further study.

\section{Adult Education}

Programs for adult education should be fostered by the university. Adult education offers an unlimited field for the education of civilians in tolerance and democratic principles. College students, if not thoroughly inoculated with these ideas, have at least been exposed to them in numerous courses and have learned to think for themselves. Too many adults depend entirely upon the newspaper, the radio, the next-door neighbor to formulate their opinions. What a wonderful opportunity for improvement is offered to a university with vision backed by a library with books to carry on the crusade. Perhaps this is not business as usual. We can make it a part of our plan.

And finally, we have an obligation to the world at large, to the libraries whose collections have been destroyed. Over twenty million books have been destroyed by bombs and incendiaries in England alone. Most university libraries in China have been the target of Japanese planes. Thousands of books have been burned, countless libraries looted. No one knows the losses. Already a member of our faculty is planning to draw from us to aid in restoring Louvain. We must save our worthwhile books and periodicals to fill the "want lists" of the unfortunate libraries of the world.

In the Pacific Northwest the university and state college libraries are playing their part in the war effort according to the needs of the area in which they are situated. The need for participating in actual war work is less apparent in institutions in the interior.

Kathleen Campbell, librarian of the University of Montana, reports :

We are so far removed from national defense activities here in Montana that we do not have very heavy demands made upon the library in the field of national defense. This library is a war information center for the state and it receives a great deal of material relating to national defense. Such material is used, of course, by the students in their regular courses. The library prepares exhibits on some phase of national 
defense for the Student Union Building about every ten days and also has material on display in the reading room in the library. We send out some material over the state to schools, clubs, and other groups for talks and discussions on the subject. The reference librarian has been called upon to answer questions relating to defense both from townspeople and from out-of-town citizens, as well as to prepare special bibliographies. Professors from the university have given talks to various clubs and groups in this city and other towns in the state on national defense and have planned their discussions around this subject for the weekly radio broadcasts sponsored by the university. Students in the debate and speech classes have centered their talks and debates around some phase of national defense and also have led group discussions pertaining to various phases of this subject.

\section{In Idaho and Oregon}

Agnes C. Peterson, reference librarian of the University of Idaho, states that because of its location the University of Idaho Library has not felt the impact of the war to as great an extent as many of the libraries of the Northwest. Their chief contribution is assistance to faculty in war research and aid to students who are shortening their college course to three years by attendance at a twelve-week summer course. The Idaho campus has been selected as a training school for naval radio operators. Men enrolled in these courses will be accorded full library privileges.

At Oregon State College emphasis has been on research. Loren G. Strawn of the reference department reports aid to Army camps such as Fort Lewis and to national defense agencies. Data was collected on air raid sirens for a municipal government and a complete bibliography on camouflage prepared for another government agency. Maps are used by the Army engineers and much work has been done on food and nutrition problems arising from the war. Two interesting bibliographies were prepared on rubber, one on synthetic rubber for a possible factory in Portland and the other on rubber and rubber plants, for a study of potentialities of the Pacific coast for rubber production from its native flora. An index of the executive orders governing the selective service both national and Oregon state was made for the local board and will be used also by the state board. At the suggestion of the campus coordinator of civilian defense a "defense table and shelf" was set up in the reading room. Little has been done in the way of service to the enlisted personnel. Soldiers stationed in Corvallis are made welcome but are not permitted to take material from the building.

\section{Union Catalog}

The Bibliographic Center of the Pacific Northwest with its union catalog at the University of Washington is proving a helpful aid in war research. The catalogs of the major libraries of the Northwest have been photographed and the holdings of each library are being transferred to the basic Library of Congress catalog. When an interlibrary loan request reaches the library and the university cannot provide the necessary books, a check is made of the union catalog. 'We know at once whether the books are obtainable in the Pacific Northwest. The saving in time is great. The Bonneville Power Administration is one of our best interlibrary loan customers. Our largest loan in one day was thirteen theses on the geology of Washington. Frequently what we are unable to supply, Seattle Public Library can. The two libraries cooperate very closely in caring for investigators' 
needs. The Boeing Aircraft Company makes all requests through the public library and we in turn lend to the public library instead of to Boeing directly. The Bremerton Navy Yard is another regular borrower through the local library at Bremerton. We were able to supply many books needed in a study to correct the very bad housing situation which prevailed among the workers in the early fall.

Library service to the men in the armed forces is carried on officially in two ways -through loans to the service club libraries or the chaplains or by actual visit of the borrower to our library. Recently letters were sent the commanding officers of twelve Army forts and fields and naval districts in Seattle and vicinity offering library facilities to the enlisted men and officers. Since then naval officers have visited our library to obtain pictures of German submarines, a doctor from the Marine hospital has requested pictures of the effects of war gas to be used on the screen, and a private from Fort Lawton has borrowed from our general reading collection. Identification is required only if books are to be taken from the library.

\section{Loans to Libraries}

Since it is difficult for men to come long distances for library service and our library is out of the city center, the loans made directly to the libraries seem to be more popular. Loan requests have been made for books on health and dietetics, military topography and map reading, calculus, breeding of horses, the Talmud, greenhouse care and culture, radio, a Russian dictionary and reader, a German dictionary and reader, books on skiing for use in writing a ski manual, and a list of books for a hobby house at Fort Raymond, Alaska. We have few requests for recrea- tional reading. Perhaps the service libraries are adequately supplied. One of our most satisfying requests came from a Seattle boy on the U.S.S. Mojave, a coast guard cutter in port at Norfolk, Va. He wanted to do some reading and thought the University of Washington in his own home town the best place to write for a reading list of classic and semiclassic literature. His letter of thanks written from Boston, his next port of call, indicated that his problem had been satisfactorily solved.

Another outgrowth of our Bibliographic Center is a venture in cooperative buying. This may not be considered a war venture nor a university venture alone but it does aid in conserving budgets, a very important factor in wartime when funds must be stretched to the utmost. About thirty libraries are buying through a joint agent. About one third are small college and university libraries.

Since early fall the staff of our library has been keenly interested in providing reading for Army camps. Before the Victory Book Campaign was organized we sponsored a campus book drive. Notices were put in the Daily, and faculty members were called individually by staff members and informed of the need for books. Over one thousand books of good titles, with clean covers, and in excellent condition were received in response. In December Helen Johns, circulation librarian, was appointed Washington director of the Victory Book Campaign. She was allowed half time with pay to take charge of the project, and office facilities in the library were made available for her and her volunteer assistants. Up to April 29, 83,563 volumes were collected in Washington. The books were distributed to forts, camps, and flying 
fields in Washington and Alaska, to service clubs in Washington and Oregon, and to the American Merchant Marine. This service will be continued for the duration. Captain Berger, Special Service Officer at the Seattle Port of Embarkation, in speaking of this service said recently, "Reading material has been found to be more important than any other factor in building and maintaining morale."

\section{Service to U.S.O. Libraries}

Several of our circulation staff have become interested in one of the U.S.O. libraries in the downtown district as a sort of extracurricular activity. They found young enlistees clamoring for textbooks in mathematics needed for examinations which they expected to take. These texts were most difficult to obtain. An appeal to Charles W. Smith, our librarian, resulted in a loan of a goodly number of books from the library's textbook collection for as long a time as needed. Later an appeal was made to the mathematics faculty which resulted in a gift collection of books large enough to satisfy the needs of the soldiers.

Most of our staff members are actively participating in recommending book purchases from various funds allotted to the library. Each staff member selects a special field in which she is interested and studies the needs of the library in that field. This too is merely applying regular procedure to the present needs. Since our budget is too limited to purchase from regular funds all current books needed on the war and postwar scene, the rental committee which meets fortnightly has emphasized purchases of this type. Book reviews are read carefully whenever there is time either in or out of the library and the meeting is devoted to a discussion of the titles recommended. The advantages are evident. A group of the staff is constantly alert and informed on the latest literature and we are at the same time able to subsidize our library collection with the most timely books in the field. Practically no processing is necessary for this collection which makes the books available almost immediately. Our students display little interest in purely recreational reading at this time but want informative factual material "hot" off the press. Our rental collection supplies it. Libraries with large book funds will doubtless have little need for service of this kind.

\section{Other Regular Functions}

Other regular library functions are proving useful in the general educative effort. The readers adviser prepares reading lists and book exhibits as needs arise on subjects such as defense of America and postwar planning. The reference department prepares bibliographies needed by faculty members, students, debaters, or government officials in their research. Incendiary bombs, gases, home protection, blackouts are among the subjects which have been covered.

The library participates actively in campus defense plans. Since the campus is located only a short distance from the Sand Point Naval Training Station the hum of the practice planes is constantly in our ears, varied now and then with the roar of a squadron flying in formation above us. When will it change to the roar of the enemy planes? No one knows. We hope never but we must be prepared. The university district is a small city in itself. To meet emergencies in the community the campus has been designated as an air raid station during the day not only for the campus population but for the 
civilian population of the immediate area. All qualified first aiders on the staff are on call and part of the library will be set aside as a receiving station. Ten members of the staff who have received first aid certificates are now practicing one and one half hours weekly on library time under a competent instructor to be prepared to assist in any emergency. Other staff members are expected to direct all occupants of the building to positions of safety when the siren sounds. Though the library has been pronounced the safest building on the campus, it also has the greatest population which places great responsibility for student safety on the staff.

\section{War Information Centers}

War information centers have been established at all of our state universities in the Pacific Northwest. Many useful and timely pamphlets have been received from the Federal government, foundations, societies, and other publishers. They cover all phases of the national defense program. At Washington a selected list of publications received has been included in the list of library accessions sent to faculty members. Pamphlets are kept apart from regular collections and displays are made in display cases and materials are used in the library as called for. Students show great interest in materials displayed and often request their use. The method of disseminating materials throughout the state is somewhat difficult and will be made through loans to small libraries as needed until our center is better advertised.

Our library has been collecting original manuscripts and journals for years. As the calls for collection of wastepaper became more and more frequent it became evident that now if ever was the time for an aggressive campaign. A university radio broadcast brought out the desirability of placing family records in a fireproof building where they would be preserved for historical purposes. The Northwest history librarian and a faculty member in the history department next visited neighboring towns where such records were known to exist. They have been generally well received and have succeeded not only in obtaining valuable papers but in making friends for the library while at the same time being engaged in protecting our cultural heritage.

\section{Preserving Rare Books and Records}

Libraries are not only depositories of rare books and records but they are responsible for their safe keeping. Since our library is adjudged the safest building on the campus not a great deal has been done about removing our rarest materials to a safer zone. As librarian and also as chairman of the Committee for the Preservation of Cultural Resources, Mr. Smith has given much thought to the problem. Plans have been made should such a need become imminent but both $\mathrm{Mr}$. Smith of our library and Mr. Jennings of the Seattle Public Library believe that our cultural resources are more important now than ever before for the preservation of morale and should be available for use as long as possible.

This report covers our work to the present moment. As the war advances, changes in personnel and instruction may change the emphasis in our daily work, but our greatest task remains the education of our youth-for them we must continue business as usual. 